\title{
Spaces apart: public parks and the differentiation of space in Leeds, 1850-1914
}

\author{
Nathan Booth ${ }^{1}$, David Churchill ${ }^{2 \star}$ (D), Anna Barker ${ }^{3}$ and Adam Crawford ${ }^{4 \dagger}$ \\ ${ }^{1}$ Independent Scholar \\ ${ }^{2}$ Centre for Criminal Justice Studies, School of Law, University of Leeds, LS2 9JT \\ ${ }^{3}$ Centre for Criminal Justice Studies, School of Law, University of Leeds, LS2 9JT \\ ${ }^{4}$ Centre for Criminal Justice Studies, School of Law, University of Leeds, LS2 9JT \\ ${ }^{*}$ Corresponding author. Email: D.Churchill@leeds.ac.uk
}

\begin{abstract}
While the Victorian ideal of the public park is well understood, we know less of how local governors sought to realize this ideal in practice. This article is concerned with park-making as a process - contingent, unstable, open - rather than with parks as outcomes - determined, settled, closed. It details how local governors bounded, designed and regulated park spaces to differentiate them as 'spaces apart' within the city, and how this programme of spatial governance was obstructed, frustrated and diverted by political, environmental and social forces. The article also uses this historical analysis to provide a new perspective on the future prospects of urban parks today.
\end{abstract}

\section{Introduction}

How might an urban historian approach the Victorian municipal park? It was both an ideal space - a jewel in the civilized and harmonious city of the future - and an actual space in which people met, played, rowed and rallied. ${ }^{1}$ This immediately suggests two broad modes of investigation: first, a cultural history of how the park was represented, and how it imaginatively constituted collective identities and attachments; second, a social history of how the park was experienced in everyday life, and how it functioned as a crucible of wider social relations. Both approaches

\footnotetext{
${ }^{\dagger}$ This article arises from an Arts and Humanities Research Council (AHRC) funded research project entitled: 'The future prospects of urban parks: the life, times and social order of Victorian public parks as places of social mixing' (Ref: AH/N001788/2), on which the authors collaborated. All named authors contributed significantly to the intellectual development of the article and approved the final version published. The first two named authors took the lead role in interpreting the data and in writing.

${ }^{1}$ H. Conway, People's Parks: The Design and Development of Victorian Parks in Britain (Cambridge, 1991), 11.

(C) The Author(s), 2020. Published by Cambridge University Press. This is an Open Access article, distributed under the terms of the Creative Commons Attribution licence (http://creativecommons.org/licenses/by/4.0/), which permits unrestricted re-use, distribution, and reproduction in any medium, provided the original work is properly cited.
} 
have yielded rich insights into the history of urban space, ${ }^{2}$ and this article draws upon aspects of each. Yet the emphasis of what follows differs from these in one important respect. Many histories of urban space dissect a given, historically specific spatial form for the insights it offers into wider cultural and social themes (such as gender norms, imperial culture or social control). By contrast, this article aims primarily to capture the Victorian park in the making. It explores how local governors (town councillors and municipal officials, sometimes with support from actors in wider civil society) practically strove to incarnate an imagined space in a specific city, and the various obstacles - political, social and environmental - they encountered in doing so. This situates the park as a work-in-progress, a necessarily unfinished project of urban governance, which articulates between the 'space in the mind' and 'spaces on the ground'.

This article focuses on park-making as a governmental process. It is concerned with the production of space rather than with space as product - with process rather than with outcome. ${ }^{4}$ As Doreen Massey observed, space is always in the process of being made. It is never finished; never closed. ${ }^{5}$ This article conceptualizes park-making generally as a process by which urban governors aim to render a given territory 'park-like' - to imbue it with the wholesome qualities associated with a certain idealized park image. Given that such images differ qualitatively from wider urban forms, it follows that parks are made as 'spaces apart' within the city. As Hazel Conway noted in the case of Victorian Britain, parks were 'created as isolated elements... which contrasted with their urban surrounding' ${ }^{6}$ Thus, parkmaking is a process of spatial differentiation. Working towards an imagined future goal, it projects what Reinhart Koselleck termed a 'horizon of expectation'; ${ }^{7}$ yet just as one never reaches the horizon, so the idealized park never quite materializes. Instead, the status of any given park hinges on how far it manifests the qualities associated with the park ideal. On this rests the park's promise to benefit the city - its promise of urban utility - and thus its claim to occupy (finite) urban space. ${ }^{8}$

\footnotetext{
${ }^{2}$ There is obviously a very sizeable body of literature on this theme: S. Gunn, 'The spatial turn: changing histories of space and place', in S. Gunn and R.J. Morris (eds.), Identities in Space: Contested Terrains in the Western City since 1850 (Aldershot, 2001), 1-14, remains a helpful point of reference.

${ }^{3} \mathrm{Cf}$. D. Cannadine, 'Residential differentiation in nineteenth-century towns: from shapes on the ground to shapes in society', in J.H. Johnson and C.G. Pooley (eds.), The Structure of Nineteenth-Century Cities (London, 1982), 235-51.

${ }^{4}$ See A. Pred, 'Place as historically contingent process: structuration and the time-geography of becoming places', Annals of the Association of American Geographers, 74 (1984), 279-97; H. Lefebvre, The Production of Space, trans. D. Nicholson-Smith (Oxford, 1991); A. Abbott, Processual Sociology (Chicago, 2016), especially ch. 6.

${ }^{5}$ D. Massey, For Space (London, 2005), 9.

${ }^{6}$ Conway, People's Parks, 7.

${ }^{7}$ R. Koselleck, Futures Past: On the Semantics of Historical Time (New York, 2004), ch. 14. See also D. Churchill, A. Crawford and A. Barker, 'Thinking forward through the past: prospecting for urban order in (Victorian) public parks', Theoretical Criminology, 22 (2018), 523-44.

${ }^{8}$ See also K. Loughran, 'Urban parks and urban problems: an historical perspective on green space development as a cultural fix', Urban Studies, forthcoming, available from https://journals.sagepub.com/doi/abs/ 10.1177/0042098018763555?journalCode=usja.
} 
This article analyses how park-making proceeded in a Victorian city, and reflects on how this history might illuminate the future prospects of urban parks today. Victorian park-making worked towards a specific park ideal - the 'people's park'. ${ }^{9}$ This park was to be an improved and improving space, which would serve as a vehicle of virtuous circulation, sanitation, moral instruction and social harmony. It was a vitalizing space - the 'lungs' of the city - which would channel fresh air through the built environment, and so strengthen the physical and moral fibre of urban inhabitants. It was a site in which the fractured social bonds of the city would be remade - where rich and poor would come to mutual understanding, and where the lower orders would internalize the refined example of their betters. ${ }^{10}$ The park's ameliorative potential stemmed from its status as a 'space apart' within the rapidly expanding city. Its greenery, pure air and open space distinguished it from the prevailing form of urban development that so concerned early Victorian commentators. ${ }^{11}$ In Helen Meller's words, the Victorians imagined the park as a 'future oasis in a desert of brick'. ${ }^{12}$ This measure of improved, ordered 'nature' - alongside numerous other 'improvements' - would sanitize, vitalize and beautify the urban landscape, transforming the city from within. ${ }^{13}$ Thus, the 'people's park' constituted a targeted, intensive intervention in the wider social body.

Oriented to this Victorian ideal, park-making comprised three interwoven strands of governmental activity: bounding, design and regulation. This article deals with each in turn. First, the park had to be demarcated from the surrounding city. This entailed acquiring sites as spaces of recreation, describing their borders and asserting municipal jurisdiction over them. Second, the park had to be made distinct from its surroundings, and cultivated so as to secure benefits to public health and morals. This involved draining, planting, laying paths, lighting and otherwise improving the site's physical fabric. Third, the park had to be made an orderly space. This meant establishing and enforcing codes of appropriate conduct. Each of these issues has been discussed before; yet conceiving of park-making as a process directs closer attention to the ongoing, everyday qualities of spatial

\footnotetext{
${ }^{9}$ See Conway, People's Parks, ch. 2; C. O'Reilly, The Greening of the City: Urban Parks and Public Leisure, 1840-1939 (Abingdon, 2019), 46-8; N. Booth, D. Churchill, A. Barker and A. Crawford, 'Experience, expectation and the evolving concept of the "people's park" in Leeds, c. 1850-1914', unpublished paper.

${ }^{10}$ Conway, People's Parks, ch. 2; T. Wyborn, 'Parks for the people: the development of public parks in Victorian Manchester', Manchester Region History Review, 9 (1995), 4-5; C. Hickman, “To brighten the aspect of our streets and increase the health and enjoyment of our city": the National Health Society and urban green space in late-nineteenth century London', Landscape and Urban Planning, 118 (2013), 114-16; K.R. Jones, "'The lungs of the city": green space, public health and bodily metaphor in the landscape of urban park history', Environment and History, 24 (2018), 39-58; Churchill et al., 'Urban order', $529-31$.

${ }^{11}$ See for example J.F.C. Harrison, Living and Learning 1790-1960: A Study in the History of the English Adult Education Movement (London, 1961), ch. 1.

${ }^{12} \mathrm{H}$. Meller, Leisure and the Changing City, 1870-1914 (London, 1976), 99.

${ }^{13}$ On 'improvement' and municipal government, see P. Joyce, The Rule of Freedom: Liberalism and the Modern City (London, 2003); and C. Otter, The Victorian Eye: A Political History of Light and Vision in Britain, 1800-1910 (Chicago, 2008). For the connection between improvement, civic culture and the urban aesthetic, see K. Layton-Jones, Beyond the Metropolis: The Changing Image of Urban Britain, 1780-1880 (Manchester, 2016).
} 
governance, and to its underlying logic. Much previous research on the origins of public parks has centred on formal planning and design in their formative years, and on outbursts of (usually short-lived) popular resistance to new parks. ${ }^{14}$ By contrast, this article stresses the protracted, prolonged and mundane quality of parkmaking, and the varied and recurrent dynamics of (often subtle) 'resistance' it encountered. ${ }^{15}$ Furthermore, having ascertained the logic of Victorian parkmaking, the concluding sections offer a new assessment of the sustainability of urban parks today, and thus use the urban past to speak to possible urban futures.

Focusing on three parks in Victorian Leeds - Woodhouse Moor (acquired in 1857), Roundhay Park (1871) and Cross Flatts Park (1889) - this article examines how parks were made in different contexts and over time. Woodhouse Moor, Leeds's first municipal park, was an historic open ground and site of local political and civic ritual, located about a mile north of the city centre in the affluent midcentury suburb of Woodhouse. Measuring approximately 60 acres, ${ }^{16}$ it was bisected by the Leeds-Otley turnpike into a bulky southern section and thin northern strip. By contrast, Roundhay Park was a residential estate, located four miles north-east of the city. Purchased by the Nicholson banking family in 1803, the vast site (well over 600 acres) was extensively landscaped early in the century, resulting in fine gardens and sweeping vistas. Cross Flatts, the smallest of the three plots (about 44 acres), was a coal-mining site owned by the Low Moor (iron) Company, located two miles south of the centre on the edge of the working-class township of Holbeck. Leeds was not a pioneer in the parks movement: by the 1850s, it was following developments in other cities, such as Manchester and Liverpool, which have provided the focus of previous case-studies. ${ }^{17}$ It was not a leader in park design and ambitions for its parks portfolio were never the greatest (not commensurate, for instance, to Liverpool's planned 'ribbon of parks'). ${ }^{18}$ This accords with the record of the municipality more generally: the council (almost invariably dominated by the Liberal party) demonstrated perhaps especially keen retrenching instincts, influenced in part by the strong voice of the retail interest in municipal politics. ${ }^{19}$ Yet

\footnotetext{
${ }^{14}$ See, among others, N. MacMaster, 'The battle for Mousehold Heath 1857-1884: "popular politics" and the Victorian public park', Past \& Present, 127 (1990), 117-54; P. Marne, 'Whose public space was it anyway? Class, gender and ethnicity in the creation of the Sefton and Stanley Parks, Liverpool: 1858-1872', Social \& Cultural Geography, 2 (2001), 421-43; P. Elliott, 'The Derby Arboretum (1840): the first specially designed municipal public park in Britain', Midland History, 26 (2001), 144-76; U. Strohmayer, 'Urban design and civic spaces: nature at the Parc des Buttes-Chaumont in Paris', Cultural Studies, 13 (2006), $557-76$.

${ }^{15}$ This draws on the broad conceptualization of 'resistance' in recent historiography: see P. Joyce, 'What is the social in social history?', Past \& Present, 206 (2010), 213-48; C. Pearson, 'Beyond "resistance": rethinking nonhuman agency for a "more-than-human" world', European Revue of History: Revue européenne d'histoire, 22 (2015), 709-25. While concerned to illustrate resistance to park-making, this article does so largely 'from above' (from the viewpoint of local governors) rather than 'from below'.

${ }^{16}$ Dimensions are taken from Yorkshire Post (YP), 1 Aug. 1911, 9.

${ }^{17}$ See for example Wyborn, 'Parks for the people', 3-14; Marne, 'Public space'; K. Layton-Jones and R. Lee, Places of Health and Amusement: Liverpool's Historic Parks and Gardens (Swindon, 2008); C. O'Reilly, 'From "the people" to "the citizen": the emergence of the Edwardian municipal park in Manchester, 1902-1912', Urban History, 40 (2013), 136-55.

${ }^{18}$ See Layton-Jones and Lee, Liverpool's Historic Parks, $25-7$.

${ }^{19}$ E.P. Hennock, Fit and Proper Persons: Ideal and Reality in Nineteenth-Century Urban Government (London, 1973), book 2, chs. 1-2; B. Barber, 'Municipal government in Leeds, 1835-1914', in D. Fraser
} 
by the late nineteenth century - thanks essentially to Roundhay - it could boast a total acreage exceeding that of its major rivals. ${ }^{20}$ It thus makes for a revealing casestudy of park-making, an undertaking of urban government that was in few respects unusual, but that left a marked impression on the urban environment.

What follows draws on extensive research from local newspapers and archival sources. Searches of digitized Leeds newspapers - including the three leading city titles, the Leeds Mercury, Leeds Intelligencer and Leeds Times - were conducted using keywords denoting the three parks. The searches covered: (1) the acquisition period for each park (the three years preceding and following the acquisition year); (2) each following census year for each park (up until and including 1911); (3) the full period following the acquisition period for each park (up until and including 1914), examining only results ranked highly for 'relevance' by the search engine. ${ }^{21}$ In this way, newspaper commentary surrounding the acquisition of each park was explored, alongside a wider sample of commentary related to each park up until World War I. This material was supplemented with extensive archival research, including minutes of the municipal Repairs Committee (which was responsible for parks in the early years) and the Corporate Property (Recreation Grounds) Committee (formed in 1873) and its sub-committees relating to specific parks. Thus, a rich and varied seam of empirical material was obtained, from which this article explores the process of park-making in the Victorian city.

\section{Bounding}

The making of Victorian parks began with bounding a portion of urban land. Purchasing land for public recreation was the first step towards designating a particular territory park space. Yet bounding parks entailed more than simply negotiating a purchase agreement; it also required orchestrating public support for the purchase, securing authority to raise funds, asserting jurisdiction over the space and maintaining its borders. The municipality was central to these activities, yet wider civil society - notably the local press - also played a role. What follows indicates that bounding parks was a contingent process: political, legal and other obstacles might obstruct it, sometimes with significant implications for the perceived prospects of individual parks.

Bounding a park involved manifesting public support for the project and following this through to a purchase agreement. The press played an important role initially: in response to moves for a new park, local newspapers across the political spectrum could usually be relied upon to stress the scheme's great merit and public enthusiasm for it. ${ }^{22}$ The Leeds Intelligencer, the city's tory journal, tended to join the liberal papers (the Leeds Mercury and Leeds Times) in supporting proposed

\footnotetext{
(ed.), Municipal Reform and the Industrial City (Leicester, 1982), 61-110. On the political composition of the council, see D. Fraser, 'Politics and society in the nineteenth century', in D. Fraser (ed.), A History of Modern Leeds (Manchester, 1980), 283.

${ }^{20}$ Higher than Bradford, Manchester, Birmingham and Liverpool: Conway, People's Parks, 73.

${ }^{21}$ Searches were conducted using the British Newspaper Archive (www.britishnewspaperarchive.co.uk/). Keywords were 'Woodhouse Moor', 'Roundhay Park' and 'Cross Flatts', each searched as a complete phrase.

${ }^{22}$ See for example Leeds Times (LT), 21 Oct. 1854, 1; Leeds Intelligencer (LI), 3 Jul. 1855, 2; Leeds Mercury (LM), 9 Aug. 1855, 2.
} 
parks; it withheld support for the exceptionally ambitious purchase of Roundhay Park, though even there its pronouncements were ambivalent rather than strongly opposed. $^{23}$ Public meetings, often well attended, also provided strong backing for the purchase of each of the case-study parks, as they did for parks in Manchester. $^{24}$ On occasion, local voluntary societies also applied pressure: in 1855, amidst fears that Woodhouse Moor would be appropriated for a militia encampment, the Leeds Recreation Society urged the mayor to convene a further public meeting, which again strongly supported acquisition. ${ }^{25}$ Yet if efforts to exhibit public support for parks were often effective, acquiring lands for public recreation was hardly straightforward. Before 1875, councils lacked powers to raise funds for this purpose, so any significant outlay often required a local act of parliament (such as the Improvement Act obtained in 1856 for Woodhouse Moor). ${ }^{26}$ Local governors sometimes devised ingenious ways of circumventing this obstacle. When the Roundhay estate came up for sale in 1871, councillors had no time to secure an act of parliament; instead, they authorized four of their number - led by Mayor Barran - to purchase the land privately, sell off excess lands for development and allow the corporation to purchase the principal out of existing funds. ${ }^{27}$

Yet purchasing parks was rarely straightforward, and could provoke conflict between localities and social interests. The proposal to purchase Woodhouse Moor - which initially also included Hunslet and Holbeck Moors, in the industrial south of the city - was criticized by representatives of Leeds's satellite outtownships, who saw the venture benefiting principally residents of the central township, and the prosperous neighbourhood of Woodhouse in particular. Debate centred on whether the cost should fall upon local residents only (through a township rate), or upon all inhabitants (via the borough fund). The scheme's supporters stressed its value to the city as a whole; one councillor urged his peers to 'look at a question of this nature, which would benefit all, irrespective of townships. (Hear, hear.) ${ }^{28}$ Yet opponents in the out-townships mounted concerted resistance early in 1856 by seeking to obstruct passage of the Improvement Bill. ${ }^{29}$ Ultimately, a House of Commons Select Committee settled upon a compromise: Woodhouse Moor alone would be purchased, out of the borough fund. ${ }^{30}$ Still, political resistance had imperilled the project, and actually prevented acquisition of Hunslet and Holbeck Moors. ${ }^{31}$ The purchase of Roundhay Park met with similar concerns. In 1871 , a public meeting in the industrial south of the city voted to delay acquisition

\footnotetext{
${ }^{23} L I, 29$ Sep. 1871, 2.

${ }^{24} L I$, 28 Oct. 1854, 9-10; LT, 28 Oct. 1854, 3; LM, 29 Sep. 1871, 4; LI, 29 Sep. 1871, 2; LM, 1 Sep. 1888,

3. On Manchester, see Wyborn, 'Parks for the people', 6.

${ }^{25} L M, 23$ Jun. 1855, 5; LI, 3 Jul. 1855, 3.

${ }^{26}$ See Conway, People's Parks, 71.

${ }^{27}$ The initial purchase cost the four councillors an astonishing $£ 139,000$ : see $L M, 30$ Sep. 1871, 5; LI, 5 Oct. 1871, 7; $L T, 2$ Dec. 1871, 3.

${ }^{28} L I, 11$ Aug. 1855, 7.

${ }^{29}$ West Yorkshire Archive Service (WYAS), Parliamentary Committee minutes LLC2/1/2, 6 Feb. 1856, 29 Feb. 1856.

${ }^{30}$ Permissive powers were awarded to other townships to purchase moors out of local rates: $L T, 19$ Apr. 1856, 5. See also G. Branston, The Commons, Waste Lands and Urban Moors of Leeds (Leeds, 2005), 28.

${ }^{31}$ The council ultimately acquired these in 1879 and 1900 respectively.
} 
and consider an alternative plan for four smaller, local parks. ${ }^{32}$ The next year, a small group of large ratepayers, concerned about the likely financial burden of such a substantial venture, ran a determined campaign against acquisition, which gave rise to considerable ill-feeling in the city. ${ }^{33}$

Even once parkland was acquired, the work of fashioning a legally and physically bounded space continued. As Woodhouse Moor was previously common land, local governors had still to assert municipal jurisdiction over the site. The council had resolved in 1855 'to extinguish the alleged commonable rights on Woodhouse and Holbeck Moors'. ${ }^{34}$ The small group of commoners would only acquiesce to this if the council vowed not to build upon or ornament the Moor (which might obstruct access) $;{ }^{35}$ however, such an undertaking would have prevented the council from improving the Moor, and hence from fashioning it into a park-like space. ${ }^{36}$ Instead, following the purchase, they undertook instead to compensate the commoners for loss of rights, yet the two sides repeatedly failed to reach a settlement. Unresolved, the issue bred uncertainty regarding the council's powers to improve the Moor: the commoners threatened an injunction to prevent alterations or adornments to the land, ${ }^{37}$ and subsequently to prevent drainage, fence-building and other works. ${ }^{38}$ As late as August 1859, councillors were still debating their own powers to alter and regulate the Moor. ${ }^{39}$

More generally, local governors had continually to preserve park boundaries against pressures of urban development. It was not always self-evident where the bounds of a park should be drawn: Woodhouse Moor and Cross Flatts Park were both situated on the edge of the city's built area (and Roundhay some miles afar); yet, as development flourished around a park, negotiation over its proper bounds might follow. There was ongoing debate over what portion of Woodhouse Moor should form the park. In 1869, Councillor Gaunt proposed selling the land north of the Leeds-Otley turnpike for residential development, on grounds that it was in poor condition and little used; yet correspondents to the press fiercely argued that the northern part had particular advantages (it was, apparently, well used by children), and that development anywhere upon the Moor would hinder the flow of air, and so prejudice its contribution to public health. ${ }^{40}$ Moves to sell part of the Moor in 1877 were also halted by opposition, ${ }^{41}$ while in 1888 plans for a temporary post-office on one corner drew threats to pull the structure down in defence of popular rights of access. ${ }^{42}$ Delineating the bounds of Roundhay Park was a similarly protracted process, complicated by the need to sell off excess land to finance improvements. Councillors failed to agree which

\footnotetext{
${ }^{32}$ LM, 29 Sep. 1871, 2.

${ }^{33}$ See $L M, 20$ Feb. 1872, 7; LT, 9 Mar. 1872, 4.

${ }^{34}$ WYAS, council minutes LL2/1/9, 28 Sep. 1855, 175.

${ }^{35} L T, 22$ Dec. 1855, 3, 8.

${ }^{36}$ The contrasting visions of the Moor at play here are analysed in Booth et al., 'People's park'.

${ }^{37}$ WYAS, municipal report books LL7/1/4, 19 Mar. 1858, 251-2, 253-4.

${ }^{38}$ WYAS, Repairs Committee minutes (RC) LLC16/1/2, 24 Jun. 1859.

${ }^{39} L M, 11$ Aug. 1859, 3.

${ }^{40} L M, 15$ May 1869, 5; LM, 18 May 1869, 3; LM, 21 May 1869, 3; LM, 25 May 1869, 7.

${ }^{41}$ See $L M, 1$ Aug. 1877, 8.

${ }^{42} L M$, 9 Jan. 1888, 8; LT, 21 Jan. 1888, 3; LT, 26 Jan. 1888, 7.
} 
grounds were integral to the Park, and which were suitable for sale: although a committee resolved in 1874 to enclose the Park, much of the land remained practically undefined, and discussions over the boundary continued for years. ${ }^{43}$ As late as 1897, the borough engineer was asked to prepare a plan for the boundary, and not until the 1900s is development visible on any part of the original estate. ${ }^{44}$ The consequent delay in selling off 'excess' land left the Park a drain on municipal funds in the 1870s and 1880s, with critics labelling it 'a white elephant'. ${ }^{45}$

Such issues were less acute where local governors were free to delineate the bounds of a newly created green space, such as Cross Flatts Park. However, even there, bounding was an ongoing process of negotiating incursions from nearby development. In 1892, planned dwellings abutting onto the Park from Dewsbury Road had to be altered, to prevent water closets (and, presumably, their attendant stink) from obstructing the entrance. ${ }^{46}$ Two years later, councillors were required to negotiate a 'give and take line' on the Park's western edge, after adjacent land was purchased for development; they soon deemed a new stone wall erected by the developer in violation of that agreement, and ordered it be pulled down. ${ }^{47}$ These might be considered 'teething' issues, to be expected immediately following acquisition; yet the integrity of any given park was always potentially subject to challenge from competing claims on the space. Almost 20 years after acquisition of Woodhouse Moor, one Mrs Blackburn, who owned a property on its western boundary, removed some nearby boundary posts, which she deemed 'an interference with....rights of horse and carriage road thereto'. ${ }^{48}$ Two years later, the Recreation Grounds Committee blocked off a new passage connecting the Moor to another property, and restricted traffic from his property to 'foot passengers' ${ }^{49}$ Thus, while governmental activity in bounding parks was most intensive during the years around acquisition, maintaining the boundary was an ongoing process which required constant vigilance and might at any moment call for renewed action.

\section{Design}

The second strand of park-making was design - improving the physical condition of park sites. While park histories tend to dwell on formal landscape planning, notable planners and questions of style, ${ }^{50}$ the basic work of design was much more improvised and mundane, focusing on improving the physical fabric of the landscape (greening, draining, planting) and constructing facilities to encourage appropriate enjoyment (laying paths, installing benches, sports pitches, bandstands and

\footnotetext{
${ }^{43}$ WYAS, Roundhay Park Committee minutes (RPC) LLC 29/4/1, 17 Sep. 1874; WYAS/RPC LLC 29/4/2, 20 Apr. 1876, 1 May 1879.

${ }^{44}$ WYAS/RPC LLC29/4/3, 2 Dec. 1897; Ordnance Survey maps, accessed via www.digimap.edina.ac.uk.

${ }^{45} L I, 19$ Sep. 1874, 5. See also $L M, 5$ Jan. 1881, 2; LT, 8 Jan. 1881, 5. Note that retrenching instincts on the council were especially strong at this time: Hennock, Fit and Proper Persons, 222-3.

${ }^{46}$ WYAS, Corporate Property (Recreation Grounds) Committee minutes (CPRGC) LLC 29/5/2, 19 Aug. 1892, 24 Aug. 1892.

${ }^{47}$ WYAS/CPRGC LLC 29/5/3, 16 May 1894, 19 Dec. 1894, 20 Jun. 1895.

${ }^{48}$ WYAS/CPRGC LLC 29/5/1, 10 Nov. 1876.

${ }^{49}$ WYAS/CPRGC LLC 29/5/2, 15 Jan. 1878.

${ }^{50}$ See for example Conway, People's Parks, ch. 5.
} 
the like). Victorian parks were meant to emplace nature in the city, yet this 'nature' had to be appropriately ordered, engineered and designed; parks were to be 'improved' green spaces, not undeveloped wastes. ${ }^{51}$ In Leeds, early efforts to design parks from existing green spaces were faltering and frustrated, yet from the 1870 s local governors enjoyed considerable success in fashioning spaces which resembled the idealized park image. As they came to create new green spaces later in the century, park design shifted from a purely post-hoc venture, initiated following acquisition, to a pre-emptive plan that presented visitors with a fait accompli - a ready-made park. Yet design was an ongoing process throughout, contingent on cost, political will and environmental constraints, and responsive to changing uses of park space; just as park boundaries had to be asserted long after they were first delineated, so too the spaces themselves had to be refined and adapted to retain mastery over a subtly resistant landscape.

Leeds's two major parks were designed on a rather ad hoc basis. Upon purchasing Woodhouse Moor, the council had no plan of how to fashion it into a park. The row with the commoners initially prevented sustained work, though the Repairs Committee made arrangements to drain, level and 'otherwise put Woodhouse Moor into good order. ${ }^{52}$ Following the Improvement Act of 1866, the council purchased and pulled down two extant sites of encroachment - small lots of houses, private gardens and outbuildings - on the heart of the Moor. ${ }^{53}$ Around this time, they obtained from Lewis Hornblower and Edouard André - noted landscape architects and park designers, who at this time were implementing their influential design of Sefton Park in Liverpool - an elaborate plan for remaking the Moor as an elegant park, complete with raised terrace, semi-circular balustrade, conservatory and promenades. ${ }^{54}$ Yet the plan was never implemented - due partly to cost, but also to a lingering sense, widely voiced in public discourse, that the Moor's simplicity was part of its character, and that elaborate ornamentation would be inappropriate. ${ }^{55}$ Similarly, there was no founding plan for Roundhay Park: 16 proposals were submitted to a competition in 1873 , yet the reaction was apparently unfavourable. Again, cost was key: the designs ranged from a considerable $£ 30,000$ to an eyewatering $£ 160,000$, on top of the already grand expense of acquiring the Park. There was also a sense that further ornamentation was inappropriate, in this case because Roundhay was already a highly designed landscape that approximated to the prevailing park ideal. ${ }^{56}$ Divisions within the council arose less between the parties than according to differentials in status: critics of further spending, who belonged chiefly to the second rank of councillors, accused the grandees of 'attempting to paint the lily, or gild-refined gold'. ${ }^{57}$ The council swiftly announced that George

\footnotetext{
${ }^{51}$ P. Borsay, 'Nature, the past and the English town: a counter-cultural history', Urban History, 44 (2017), $30-1$.

${ }^{52}$ WYAS/RC LLC16/1/2, 26 Aug. 1859, 29 Apr. 1860.

${ }^{53}$ WYAS, Improvement Amendment Bill (1865) QE20/1/1865/12; Branston, Urban Moors, 28.

${ }^{54} L M$, 29 Sep. 1868. (The authors are grateful to Bill McKinnon for bringing this article to their attention.) On Sefton Park, see Conway, People's Parks, 97-100.

${ }^{55}$ See further Booth et al., 'People's park'.

${ }^{56}$ Advertisements for sale of lots from the original estate noted their 'park-like' enclosures and the 'richly-wooded landscape unsullied by the smoke of the town': $L M, 27$ Aug. 1870, 2; $L M, 8$ Apr. 1871, 2.

${ }^{57} L I, 6$ Sep. 1873, 5. See also $L M, 25$ Sep. 1873, 3; LM, 4 Dec. 1873, 8; LI, 6 Dec. 1873, 6.
} 
Corson's winning design (estimated at around $£ 67,000$ ) would not be implemented. $^{58}$

Despite these faltering beginnings, the last quarter of the century saw significant work to improve parks through design. The transformation was most stark on Woodhouse Moor, which, during the 1870 s, apparently went from a 'standing disgrace' to 'the most popular promenade in the town'. ${ }^{59}$ Successive improvements re-forming and levelling the land, planting trees and shrubs, erecting fences, laying concrete and cement pathways, installing seats, ornamental arches, a fountain and bandstand - produced a much changed (though still recognizable) landscape. ${ }^{60}$ Visual evidence best captures the altered appearance of the Moor around this time; though sparsely deployed, the Moor's new routes and ornaments lent it aspects fit for an Edwardian civic postcard (see Figures 1-3). Modest improvements were made at Roundhay too, including laying out the 'New Walk' from the Mansion to Prince's Avenue, and the already standard accoutrements of benches, shelters, a bandstand and (highly ornamented) drinking fountain. As previous studies have amply demonstrated, such architecture aimed to harness the civilizing influence of 'nature' to cultivate refinement amongst visitors. ${ }^{61}$ Parks were thus rendered useful, as spaces of improvement, cementing their claim to urban space.

Park design proceeded most efficiently at Cross Flatts. Acquired later, it followed the significant advances made at Woodhouse Moor, Roundhay and elsewhere. ${ }^{62}$ Moreover, as Cross Flatts Park was a newly created green space, fashioned from a coal-mining site ('of so straggling a character'), ${ }^{63}$ the council enjoyed a free hand to craft it in likeness of the idealized park image, unencumbered by existing social experiences of, and attachments to, the space. It was thus a blank slate, and the borough engineer (who, prior to the appointment of a parks superintendent in 1901, was responsible for major design work) spent two years developing the site prior to the public opening. The Corporate Property Committee opted for a plan which 'made the most of the space', incorporating football and cricket pitches, gymnasiums, an open area 'upon which infants may make merry' and a shrubbery running 'entirely around the site'. The shrubbery border helped to demarcate the Park's boundary long before it was enclosed on all sides by new housing. ${ }^{64}$ Despite a few amendments, the essence of the plan was implemented by the summer of $1891 .^{65}$ It was meant as 'a park for light games' - most appropriate, the committee supposed, for a working-class district. Yet significant investment in sporting facilities reflected a wider turn in park design - and in the broader park ideal towards physical exercise and organized recreation. ${ }^{66}$ This left its mark more lightly

\footnotetext{
${ }^{58}$ LI, 30 Jan. $1874,4$.

${ }^{59}$ LM, 30 Sep. 1871, 5; Yorkshire Post and Leeds Intelligencer (YPLI), 18 May 1881, 2.

${ }^{60}$ See LM, 21 Nov. 1871, 7; WYAS/CPRGC LLC 29/5/1, 19 Feb. 1885; LT, 9 May 1891, 5.

${ }^{61}$ See especially Conway, People's Parks.

${ }^{62}$ By 1889, the council had acquired 13 parks: YP, 1 Aug. 1911, 9.

${ }^{63} L T, 27$ Sep. $1890,5$.

${ }^{64} L T, 27$ Sep. $1890,5$.

${ }^{65}$ LT, 27 Jun. 1891, 5.

${ }^{66} \mathrm{C}$. O'Reilly, "We have gone recreation mad": the consumption of leisure and popular entertainment in municipal public parks in early twentieth-century Britain', International Journal of Regional and Local History, 8 (2013), 112-28.
} 


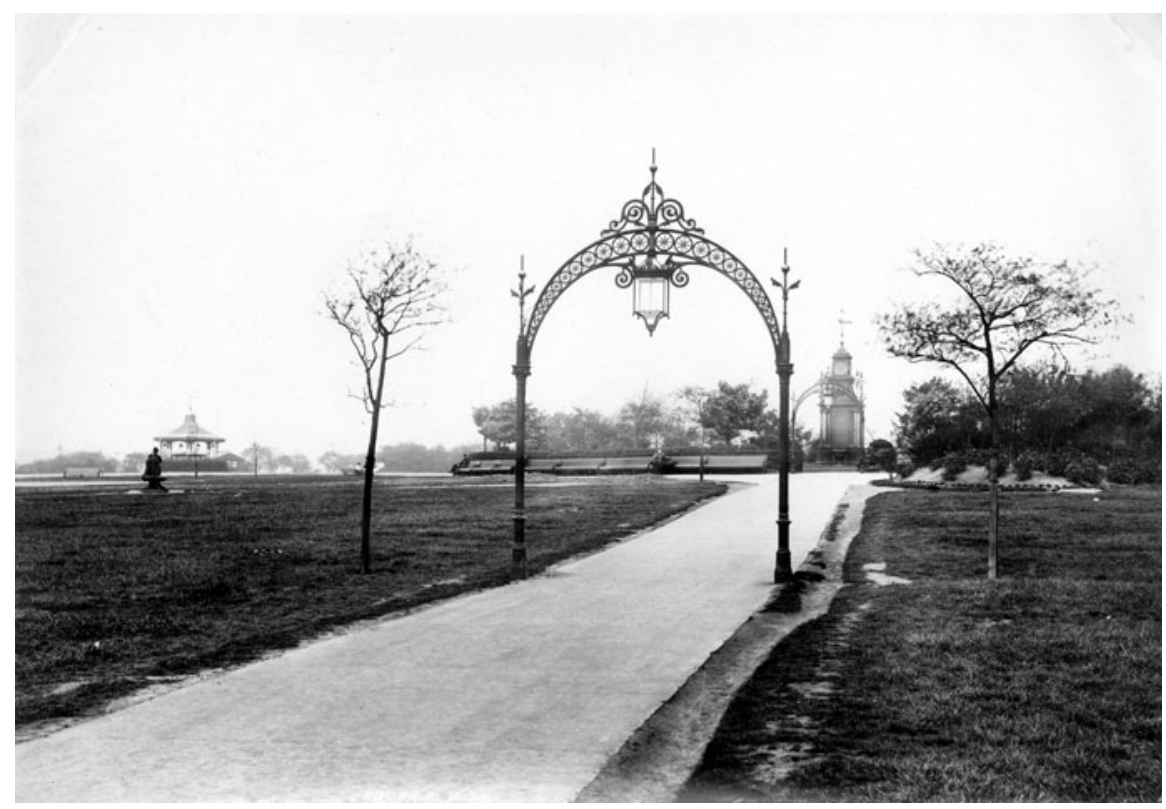

Figure 1. Woodhouse Moor, 1897. Though still recognizably a moorland landscape, the late century park was decorated with ornamental arches, a grand fountain, bandstand and other features.

Source: www.leodis.net (image ID: 2004311_32226199). Image reproduced courtesy of Leeds Library and Information Services. Please note this image is made available under a CC BY-NC-SA licence. See: https://creativecommons.org/ licenses/by-nc-sa/4.0/.

on the other parks: Woodhouse Moor acquired a bowling green in the early 1900s, and a large outdoor cycling track was formed at Roundhay. ${ }^{67}$

Even where the council had the funds and political will to press ahead with improvements, the process of park design was not always straightforward. An important, subtle source of 'resistance' came from park landscapes themselves. Poor weather could at least temporarily undo the efforts of gardeners to render improved spaces. One observer noted in 1871 that, despite recent improvements, 'During the winter, especially during wet weather, or after a thaw, Woodhouse Moor presents the enticing appearance of a quagmire. ${ }^{98}$ Some works ran into technical challenges: by 1891, paths recently laid on Cross Flatts Park had sunk, and were now 'six to eight inches lower than the grass'. ${ }^{69}$ Past uses of park sites might also return to haunt gardeners, as in 1881 when land on Woodhouse Moor formerly occupied by the Manor House Inn (an encroachment pulled down over 10 years previously) suffered subsidence, necessitating impromptu digging around the spot to prevent people falling in. ${ }^{70}$ Improvements such as planting also took time to come to fruition: new trees were often delayed by the vagaries of

\footnotetext{
${ }^{67}$ Ordnance Survey maps, accessed via www.digimap.edina.ac.uk.

${ }^{68}$ LM, 28 Sep. 1871, 6.

${ }^{69} L T, 25$ Jul. $1891,5$.

${ }^{70} L M, 30$ Mar. 1881, 5.
} 


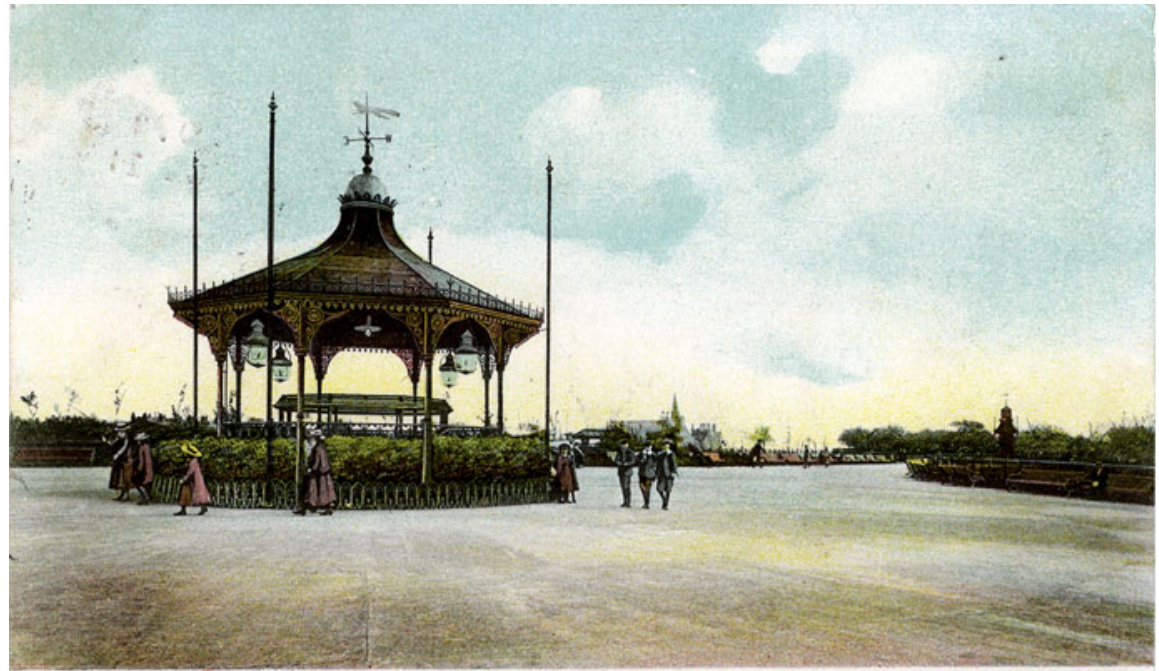

Woodhouse Moor

LEEDS

Figure 2. The bandstand on Woodhouse Moor, c. 1905. The bandstand was donated by Alderman William North, but note also the large paved surface (c. $45 \mathrm{~m}$ in diameter) surrounding it. North also donated the ornamental fountain, just visible to the right.

Source: www.leodis.net (image ID: 2011726_172449). Image reproduced courtesy of Leeds Museums and Galleries. Please note this image is made available under a CC BY-NC-SA licence. See: https://creativecommons.org/ licenses/by-nc-sa/4.0/.

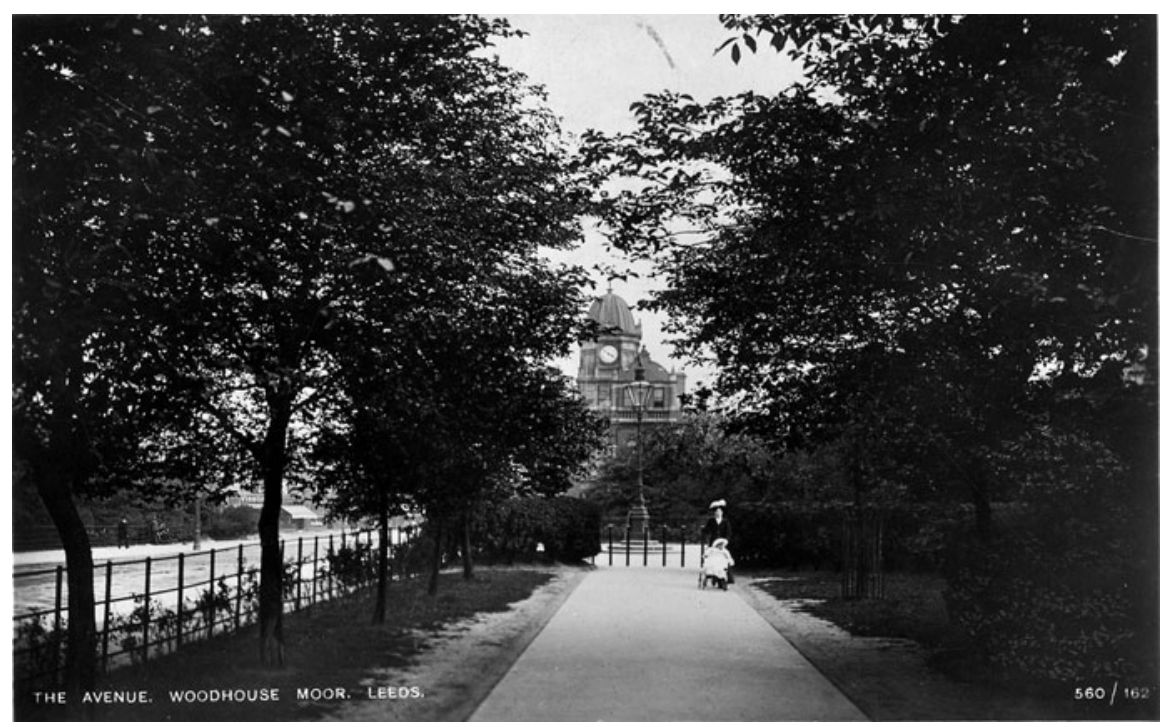

Figure 3. 'The Avenue', a popular tree-lined promenade, leading to the drinking fountain, c. 1916. Woodhouse Lane (formerly the Leeds-Otley turnpike), visible left, is screened by trees.

Source: www.leodis.net (image ID: 2011726_172451). Image reproduced courtesy of Leeds Museums and Galleries. Please note this image is made available under a CC BY-NC-SA licence. See: https://creativecommons.org/ licenses/by-nc-sa/4.0/. 
the seasons, or by the effects of urban smoke, despite gardeners' efforts to nurture strong growth. ${ }^{71}$

Further resistance to design came from park users themselves. In some instances, this resulted from lack of the facilities necessary to accommodate large numbers: in 1881, complainants noted that an increase in visitors to Woodhouse Moor (following installation of the fountain) had resulted in severe loss of grass at the edges of pathways, and called for better concreted walkways. ${ }^{72}$ Users also subtly reshaped the landscape to meet their needs: indeed, that winter, the Corporate Property Committee commissioned a plan indicating the various footpaths which visitors had worn into the Moor. ${ }^{73}$ In such cases, further improvements might overcome the difficulties identified; yet not all damage was so easily rectified. To counter fully threats to park landscapes - and more broadly to fashion improved and improving park spaces - local governors were obliged also to regulate the conduct of park users.

\section{Regulation}

As spaces of improvement, local governors purposely opened parks to most of those they deemed in need of moral betterment. Yet the improving potential of parks derived from their civil and edifying environment. Hence, for parks to serve as improving spaces, it was necessary to regulate visitors' conduct. This was a founding assumption of the park movement: the report of the Select Committee on Public Walks (1833) had called for parks for the lower orders, 'under due regulations to preserve order. ${ }^{74}$ However, park regulation differed from the policing of other public spaces in both its means and its ends. This section shows how local governors struggled to strike a satisfactory balance between under- and overregulation of park users - caught between the determination to expose ordinary people to the improved park environment, and the need to safeguard that environment against disorderly intrusions.

There were three broad objectives of park regulation. First, it aimed to insulate the park from a residuum of 'offensive' figures, including vagrants, gypsies and livestock. As an improved (and improving) space, the park could not tolerate all persons or things which might come within its bounds. Second, regulation aimed to protect the park landscape from its users, sanctioning those who spoiled it and guiding others toward less disruptive practices. The fabric of the park had to be protected to sustain its claim to serve as an improving space. Third, regulation aimed to prevent 'deviant', hazardous or monopolistic uses of park space. To maximize the park's potential for vitalization and moral improvement, local governors sought to facilitate use by the greatest possible number of appropriate visitors; hence, practices which might interfere with others' legitimate enjoyment - such as cycling or playing ball games - were subject to regulation.

\footnotetext{
${ }^{71} L M, 23$ May 1872, 8; YPLI, 18 May 1881, 2.

${ }^{72} L M$, 23 Jul. 1881, 7; LT, 30 Jul. 1881, 4; LT, 24 Sep. 1881 5. See also $L M, 20$ Apr. 1888, 7.

${ }^{73}$ WYAS/CPRGC LLC 29/5/1, 29 Nov. 1881.

${ }^{74}$ British Parliamentary Papers, Report from the Select Committee on Public Walks (1833), 8.
} 
Perhaps the most obvious instruments of park regulation were local by-laws. ${ }^{75}$ In Leeds (as in Manchester), by-laws empowered 'Servants of the Corporation' to remove particular classes of person from the parks, including gypsies and vagrants - yet mostly they aimed at 'regulating the Conduct of Persons frequenting any such Place of Recreation'. 76 These injunctions touched upon an extremely wide range of behaviours, most of which threatened damage to the park landscape: destroying trees; picking flowers; driving and parking carts and waggons; depositing building materials; drying clothes and shaking carpets; erecting stalls, booths or hustings; cutting the soil; catching birds or worrying animals; fishing and bathing in the lakes; driving animals and training horses. Others centred on potentially monopolistic uses of park space, which might impinge upon others' legitimate enjoyment. By-laws for Woodhouse Moor laid down in 1870 prohibited shooting and racing matches, knor and spell ${ }^{77}$ and 'any other game' (except cricket) considered dangerous, injurious to the land or which may 'interfere with the safety or comfort of the general public, in the use of the said Moor'. ${ }^{78}$ The point was put especially clearly under the by-laws of 1906, which prohibited any game which 'may necessitate... exclusive use by the player or players of any space in the Recreation Ground', with the exception of spaces purposely provided for particular games. ${ }^{79}$ Generally, the by-laws were enforced in a discretionary manner. True, by the later nineteenth century, a steady stream of petty miscreants appeared before the city's magistrates, including numerous children fined for damaging trees or shrubs, plucking flowers and such like. ${ }^{80}$ But the relevant municipal committees frequently demanded an apology from offenders, in the first instance, rather than pursuing them through the courts. The Recreation Grounds Committee even asked a man suspected of taking a sod from Woodhouse Moor to return it to them, to forestall legal action. ${ }^{81}$

The enforcement of such regulations depended upon both formal and informal custodians on the ground. The park was a space of multi-tiered regulation: more so than the street, it was formally policed by several agencies, which co-existed and overlapped. ${ }^{82}$ Park rangers were seemingly responsible, in the first instance, for discharging drunken visitors; on occasion, they literally carried intoxicated individuals out of the park, or bundled the more riotous drunks into a cab for despatch to the nearest police station. ${ }^{83}$ The police helped to promote order, especially by removing

\footnotetext{
${ }^{75}$ See also Marne, 'Public space', 432.

${ }^{76}$ Leeds Local and Family History Library (LLFHL), local by-laws (LBL) LP 352.681 L517 (1871), 4, 3. On Manchester, see O'Reilly, Urban Parks, 59-60.

${ }^{77} \mathrm{~A}$ popular bat-and-ball game played in the West Riding of Yorkshire; the object was to hit the 'knor' (a small ball) as far as possible with a stick ('spell'). See: http://woodhousemooronline.com/?p=1352.

${ }^{78}$ LLFHL/LBL LP 352.681 L517 (1871), 6. See also WYAS/CPRGC LLC 29/5/1, 13 May 1878.

${ }^{79}$ LLFHL/LBL LP 352.681 L517 (1906), 12.

${ }^{80}$ LT, 2 May 1874, 5; LI, 16 May 1874, 5; Yorkshire Evening Post (YEP), 29 Jun. 1891, 3; YEP, 28 Jul. 1891, 4; YEP, 19 Aug. 1891, 3.

${ }^{81}$ WYAS/CPRGC LLC 29/5/1, 27 Jun. 1879, 9 Jul. 1880. See also LI, 6 Jun. 1873, 1; WYAS/CPRGC LLC 29/5/7, 14 Sep. 1908.

${ }^{82}$ On the patchwork of urban law-enforcement generally, see D. Churchill, Crime Control and Everyday Life in the Victorian City: The Police and the Public (Oxford, 2017).

${ }^{83}$ Leeds Daily News, 8 Apr. 1882; LT, 11 Jul. 1885, 3. Unsurprisingly, rangers sometimes exceeded their duty in dealing with drunken visitors: see $L M, 6$ July 1881, 2; $L M, 4$ Aug. 1881, 3.
} 
drunks, vagrants and other disorderly persons. In 1857, the Watch Committee decided to site a new police station for the north of the city on the edge of Woodhouse Moor, and the Repairs Committee instructed the station sergeant 'to inspect and take care of Woodhouse Moor, reporting all nuisances to this Committee. ${ }^{84}$ Yet supervision of parks was liable to fall below more pressing police priorities, especially given frequent shortages in manpower: by the early twentieth century, it seems the Leeds Police had ceased routinely to supervise parks and open spaces. ${ }^{85}$ Park-keepers and gardeners doubtless played an important role in encouraging good conduct, though they have largely escaped the historical record. They were materially assisted by the Watch Committee: as in Manchester and Liverpool, park staff were formally sworn in as police constables, and thereby endowed them with broad police powers to regulate public space. ${ }^{86}$ Finally, park users themselves sometimes helped to enforce order. On a public open day at the Roundhay estate, shortly before the council acquired the site, six 'self-appointed guardians' reprimanded a boy for climbing a tree, and elicited from him a promise to behave better in future. ${ }^{87}$

Park governors also used technical means to regulate behaviour and promote good order. Fences, railings, paths and gates - as much as park-keepers or police constables - helped to orient park users to behave appropriately. The basics of park design - laid pathways, tree lines, emplaced seating - subtly guided visitors towards orderly and fulfilling conduct (promenading, listening to concerts, taking in the gardens). Fences sometimes erected along the principal promenades purposely directed walkers, rather than leaving them to roam aimlessly. ${ }^{88}$ More noticeable barriers aimed to prevent damage: in 1880, iron hurdles were installed to enclose the shrubberies surrounding the fountain on Woodhouse Moor, presumably to prevent visitors from upsetting the plants. ${ }^{89}$ When an outdoor gymnasium was provided in 1888, it was locked to prevent use on Sundays, as were the children's swings. ${ }^{90}$ Such technical measures were intended to facilitate virtuous enjoyment, and hence to promote moral improvement. Boundary walls and fences perhaps served a similar purpose: standing little more than waist-height, ${ }^{91}$ they were perhaps intended to prevent unthinking, uncommitted uses of the park as a pedestrian cut-through, for example - rather than as sites of purposeful selfimprovement (though some fencing was clearly intended to prevent non-human traffic straying onto parks). ${ }^{92}$ By the turn of the twentieth century, councillors

\footnotetext{
${ }^{84}$ WYAS/RC LLC16/1/2, 11 Dec. 1857.

${ }^{85}$ Application by the Chief Constable for Additional Men for the City Police Force (Leeds, 1902), 11.

${ }^{86}$ West Yorkshire police records database (2014), register of applicants, Leeds Police, available from: www.ancestry.com; WYAS, Watch Committee minutes LLC5/1/14, 23 Jul. 1886, 359. On Manchester, see Wyborn, 'Parks for the people', 8; on Liverpool, see Marne, 'Public space', 436.

${ }^{87} L T, 30$ Mar. 1872, 5.

${ }^{88}$ WYAS/CPRGC LLC 29/5/3, 7 Sep. 1893; WYAS/CPRGC LLC 29/5/4, 15 Jan. 1897; WYAS/CPRGC LLC 29/5/6, 17 Feb. 1904. See also Strohmayer, 'Parc des Buttes-Chaumont', 564-5; Loughran, 'Cultural fix', $10-11$.

${ }^{89}$ WYAS/CPRGC LLC 29/5/1, 9 Jul. 1880. See also WYAS/CPRGC LLC29/5/6, 14 Apr. 1902.

${ }^{90}$ WYAS/CPRGC LLC 29/5/2, 21 Feb. 1888, 13 Jul. 1888; LT, 14 Jul. 1888, 3. Swings were similarly locked in Manchester's parks: Wyborn, 'Parks for the people', 10.

${ }^{91}$ See for example WYAS/CPRGC LLC 29/5/2, 16 May 1890.

${ }^{92}$ By-laws laid down in 1906 proscribed entrance to or exit from parks except through the gates, wickets or passages provided: LLFHL/LBL LP 352.681 L517 (1906), 6. In 1895, a palisade was fixed around a gate at
} 
were using fencing more obviously to restrict access for visitors. In the 1890s, a four-foot-six-inch fence was erected further around the perimeter of Woodhouse Moor, and subsequently made 'unclimbable'. ${ }^{93}$ Shortly after Cross Flatts Park was opened, the Recreation Grounds Committee had the gates padlocked shut one hour after sunset, to prevent night-time access, and provided an 'unclimbable iron fence' for part of the southern and south-eastern boundary. ${ }^{94}$

The last major means of regulating behaviour was zoning - purposely restricting certain activities to specific areas within a park. ${ }^{95}$ In a banal though diffuse sense, most recreations came to be appropriate only in approved areas; the by-laws enacted in 1882 permitted no visitor to 'walk or remain upon any part of any Recreation Ground where a notice is placed requesting persons not to walk upon such part or forbidding its use. ${ }^{96}$ Besides protecting vulnerable parts of the landscape - the flower beds, borders, shrubberies - zoning aimed to contain potentially monopolistic uses of park space. It first did so to regulate games of knor and spell on Woodhouse Moor: following complaints from passers-by struck by stray balls, the Repairs Committee resolved in 1859 to restrict play to the northern section (over the turnpike road), excluding players from the heart of the Moor. ${ }^{97}$ Over time, several potentially offensive activities were confined to this part of the Moor, from grazing sheep to shaking carpets. ${ }^{98}$ Such 'compound zoning', though, might jeopardize the relevant territory's claim to park status; indeed, we have seen that, by the late 1860 s, there were already moves to sell off this part of the Moor. Pushed this far, zoning distinguished not just different portions of park space, but also more or less park-like spaces.

Regulating park users' conduct presented local governors with an essential dilemma. On the one hand, as improved spaces, they hoped the park would stand as a crucible of decorous public conduct; yet as improving spaces, parks had to admit those in need of their civilizing influence, and hence to make some accommodation for unrefined conduct. The council's attempt to strike a balance between discipline and licence left them vulnerable to criticism for over- or underenforcement. Loudest were those who decried the lack of good order. Residents and journalists complained of diverse nuisances and transgressions, including disorderly crowds of boys, offensive language and furious riding of bicycles. ${ }^{99}$ The by-laws were apparently widely flouted; the police were either ineffectual or absent entirely. ${ }^{100}$ There were occasionally more serious complaints too - of sexual

the southern end of Cross Flatts Park specifically to exclude cattle: WYAS/CPRGC LLC 29/5/3, 18 Dec. 1895.

${ }^{93}$ WYAS/CPRGC LLC 29/5/4, 12 Mar. 1897, 28 Mar. 1898.

${ }^{94}$ WYAS/CPRGC LLC 29/5/3, 26 Apr. 1894; WYAS/CPRGC LLC 29/5/2, 26 May 1892, 235; LI, 4 Sep. 1893 , p. 6.

${ }^{95}$ See also discussion of zoning and the 'variegated park' in A. Barker, A. Crawford, N. Booth and D. Churchill, 'Park futures: excavating images of tomorrow's urban green spaces', Urban Studies, forthcoming, available from https://journals.sagepub.com/doi/full/10.1177/0042098019875405.

${ }^{96}$ LLFHL/LBL LP 352.681 L517 (1882), 4-5.

${ }^{97}$ WYAS/RC LLC16/1/2, 26 May 1859. The game was prohibited outright in 1867: see Churchill et al., 'Urban order', 532.

${ }^{98}$ WYAS/CPRGC LLC 29/5/1, 14 Mar. 1878, 1 Jul. 1884.

${ }^{99}$ See for example $L M, 10$ Oct. 1863, 7; LM, 6 Aug. 1864, 9; LT, 21 May 1881, 5; LM 20 Apr. 1888, 7; YEP, 11 Jan. 1901, 3.

${ }^{100}$ YEP, 26 Feb. 1901, 3. 
deviance (exposure, 'hedge creeping', 'immoral connextions', child molestation), and, by the early twentieth century, of 'hooligans' and 'ruffianism', notably at Woodhouse Moor and Cross Flatts Park. ${ }^{101}$ Such forms of behaviour - in greater or lesser degree - threatened to pollute the park's improved environment. Yet others complained that park regulation was unduly strict - that restrictions on cricket, cycling, pierrots and singers hindered appropriate enjoyment. ${ }^{102}$ In regulating such uses, the authorities were in danger of deterring a portion of the urban populace from using the park, and so of failing to cascade the park's civilizing effects.

\section{Making and unmaking urban parks}

Today, especially following the fiscal fallout from the financial crisis of 2007-08, urban parks in the UK face an existential threat. How might the above analysis of parks as spaces-in-the-making, and of Victorian practices of park-making specifically - inform how we make sense of these contemporary challenges? This section probes more closely the logic of park-making as a governmental process, and assesses the implications of this analysis for the making (and, potentially, the unmaking) of contemporary urban parks. ${ }^{103}$

This article has suggested that park-making is a process of fashioning discrete urban territories into distinctive, 'park-like' spaces - 'spaces apart' within the city - which embody qualities associated with an idealized park image. The park's claim to urban space rests on the benefits it promises to confer to the wider city. Two further points should be noted at this stage. First, as an intensive intervention in the urban environment, park-making comes with significant costs. Most obvious are direct costs: land, facilities, materials, equipment and labour. Yet equally significant - especially within more formal urban planning regimes ${ }^{104}$ - are opportunity costs. Fashioning a territory into a park means not developing it in any number of other ways - as a housing estate, business centre, industrial plant, transport hub which would deliver other benefits. Thus, advocates of the park stake their claim to urban space by promising differential benefits, relative to other forms of urban development - a particular utility in the spatial economy of the city. Second, parks which ultimately fail to resemble the idealized park image risk facing one of two fates: it may become undifferentiated from wider urban space (not be recognized as a park) or it may fail to deliver sufficient differential benefits for the city (and so be seen, at best, as a waste of space). In the latter case, as parks are relatively lightly developed spaces, they are perhaps especially liable to be seen as wastes: as transitory and liminal urban sites, ripe for (re)development. ${ }^{105}$ Hence, park-making

\footnotetext{
${ }^{101}$ On sexual misconduct, see $L T, 15$ Aug. 1885, 5; YEP, 19 Oct. 1911, 5; YEP, 29 May 1913, 3. On 'hooliganism', see YEP, 11 Jan. 1901, 3; YEP, 17 Jul. 1901, 3; YEP, 13 Sep. 1911, 3; LM, 7 Sep. 1907, 7. For similar problems in Liverpool, see Marne, 'Public space', 435-6.

${ }^{102} L M$, 24 Aug. 1863, 3; LM, 12 Jan. 1881, 2; YEP, 22 Sep. 1891, 4; YEP, 2 Oct. 1908, 4; WYAS/CPRGC LLC 29/5/7, 26 Jul. 1911.

${ }^{103}$ For a more general analysis of 'possible futures' for UK urban parks, see Barker et al., 'Park futures'.

${ }^{104}$ On the rise of urban planning, see H. Meller, Towns, Plans and Society in Modern Britain (Cambridge, 1997).

${ }^{105}$ On parks and wastes, see MacMaster, 'Mousehold Heath', 120-1.
} 
generally acts to keep a park from blending in with the surrounding city or from degenerating into a waste.

Over time, the idealized image which orients park-making has shifted considerably. Already by the late Victorian and Edwardian period, the vision of social mixing and pure air had started to yield to that of vigorous exercise and active citizenship. ${ }^{106}$ In the hundred years since, the telos of park-making has shifted still further, reflecting profound changes in urban governance, public space and wider social formation. Park managers today often articulate the park's value in terms of 'public health', 'social cohesion' and 'community building', yet these terms are not analogous to Victorian ideas of vitalization, emulation and civilization. ${ }^{107}$ Moreover, as Conway has argued, the conceptual clarity of the Victorian park - as a discrete, delimited urban space - blurred over the twentieth century, with the rise of parkways, park systems and chains, and even extra-urban 'national' and 'country' parks. ${ }^{108}$ Yet, despite these adaptations, the underlying logic of urban park-making persists into our time. Most park managers still seem to conceive of the park ideally as a 'space apart', distinct from other kinds of urban space, which promises to deliver differential public benefits. Park-making largely remains a project of urban spatial differentiation, of rendering discrete urban territories 'parklike' (though according to altered qualities of 'park-likeness'), and of preventing them from degenerating into wastes. At this basic level, parks which survive and thrive today do so because they have made good their promise to benefit the city and its inhabitants in a way that other uses of the space would not. ${ }^{109}$

Thinking about park-making as a continual and contingent process offers a new perspective on the challenges currently facing urban parks in the UK. With the onset of austerity politics since 2010, public parks have faced acute reductions in funding (with losses of over 40 per cent to local authority parks budgets). ${ }^{110}$ Meanwhile, at least in major cities such as Leeds, there has been little reduction in demand for urban space: house prices in Leeds rose 18 per cent from 2010 to 2018, and the city has seen continued urban redevelopment, especially in the city centre. ${ }^{111}$ This confluence of public funding restraint and continued urban development poses a systemic threat to public parks. Strong demand for urban space raises the opportunity costs of park-making - parks have to meet an escalating threshold of value. ${ }^{112}$ At the same time, budget cuts undermine the ability of park managers to realize the benefits of parks - to public health, social cohesion, education and environmental protection. Under these conditions, parks are at

\footnotetext{
${ }^{106}$ See H. Conway, 'Everyday landscapes: public parks from 1930 to 2000', Garden History, 28 (2000), 118-19; O'Reilly, 'Edwardian municipal park', 145-6, 150-3; O’Reilly, 'Recreation mad'.

${ }^{107}$ See Churchill et al., 'Urban order', 534-6.

${ }^{108}$ Conway, 'Everyday landscapes', 117-34.

${ }^{109}$ See also Loughran, 'Cultural fix'.

${ }^{110}$ K. Layton-Jones, Uncertain Prospects: Public Parks in the New Age of Austerity (London, 2016), 2.

${ }^{111}$ Data from www.centreforcities.org/data-tool. More widely, see Layton-Jones, Uncertain Prospects, $15-16$.

${ }^{112}$ This underlying pressure is compounded by specific demands of contemporary policy-makers that parks make more, wider-ranging and better-evidenced contributions to public goods: see Barker et al., 'Park futures'.
} 
risk of failing to stake a compelling, distinctive claim to urban utility, and thus increasingly in danger of being perceived as wastes.

Furthermore, some responses to these challenges may exacerbate the difficulty of sustaining parks as beneficial spaces apart. Many park managers increasingly seek commercial opportunities, to obtain additional revenue. Such strategies can help to protect budgets, attract visitors and enhance user satisfaction. However, increasingly visible commercial activity in parks may ultimately undermine the differentiation of park space. If highly commercialized parks come increasingly to resemble the wider city, their claim to offer differential urban utility may be diluted. ${ }^{113}$ Alternatively, some see the future of urban parks best safeguarded by integrating them with other forms of green space. For example, under the rubric of 'green infrastructure', parks are to be emplaced within wider networks of green space, which are essential to the functioning of the city. Yet this advances a claim to urban utility for green infrastructure as a whole, rather than for parks specifically. Unless accompanied by recognition of the differential value of park space, one can imagine how urban green infrastructure might ultimately be rationalized to the detriment of parks. ${ }^{114}$ Equally, the emerging trend towards 'greening' urban space at large may seem favourable to urban parks, with the streets and squares of major cities increasingly used as flexible spaces of recreation, relaxation and play (including via 'pop-up' parks and other creative interventions). ${ }^{115}$ Such developments are at present modest in scale; yet a thoroughgoing 'greening' of urban public space may actually undermine the differential between park space and wider urban space, upon which the value of parks has long been founded. It is at least conceivable that the 'greening' of the city may lead to the 'greying' of the park, with the park losing its promise of differential urban utility in the process.

\section{Conclusion}

This article has analysed park-making in Victorian Leeds as a contingent and necessarily unfinished process, whereby local governors sought to bound, design and regulate particular territories as parks. These governmental practices aimed to render parks improved 'spaces apart' within the city, which would function as spaces of improvement - ameliorating the urban environment and elevating the condition of its inhabitants. Park-making did not always run smoothly: it had to contest with political discord, legal hurdles, 'resistant' landscapes and disobedient park users. With time, though, local governors became more adept at directing the process of park-making: they proceduralized much of the work of bounding and design, which were pursued much more efficiently at Cross Flatts than earlier at Woodhouse Moor or Roundhay. From the 1880s, they also took a more proactive approach to governing their expanding parks portfolio. As Carole O'Reilly has

\footnotetext{
${ }^{113}$ See also discussion of the 'theme park' in Barker et al., 'Park futures'.

${ }^{114}$ Indeed, some scholars advocate marginal green spaces in preference to parks, on grounds of social and environmental justice: J.R. Wolch, J. Byrne and J.P. Newell, 'Urban green space, public health, and environmental justice: the challenge of making cities "just green enough", Landscape and Urban Planning, 125 (2014), 234-44.

${ }^{115}$ On pop-up parks, see https://www.popupparks.org.uk/.
} 
argued, park management seems to have reflected the growing confidence of urban elites and municipal government in the late Victorian and Edwardian era. ${ }^{116}$ Progress in regulating park users was much more variable. Regulation rubbed against the twin dangers of over- and under-enforcement - either deterring potential beneficiaries from the park's civilizing influence, or eroding the park's capacity to exercise any such influence at all. In this area above all, one sees that parkmaking, even in its late Victorian and Edwardian heyday, was never complete, but always in process.

Furthermore, this analysis offers insights into the prospects of urban parks today. It would be easy to see funding restraint as the latest external threat to the once secure municipal park. Conceived as process, though, urban space is never secure - the prospect of radical change is ever present. As Katy Layton-Jones argues, 'we underestimate the efforts and resources always required to keep threats [to public parks] at bay'. ${ }^{117}$ The park's claim to urban space rested (and rests still) on practices of park-making - on continual governmental action - and public responses to it. Reductions in funding and intensified demand for urban space together pose a systemic threat to the sustainability of parks as beneficial 'spaces apart'. In different ways, the commercialization of parks and the greening of the city may undermine the spatial differentiation upon which the park's existence has long been premised. For over 150 years, park-making has proceeded from the recognition that cities need parks - that park space, appropriately governed, has potential to deliver unique benefits to the city and its inhabitants. The future of parks as we have long understood them rests on sustaining such a claim in a uniquely challenging context. Those wishing to defend and secure the future of parks would be well advised to think creatively about how the differential value of park space may be reasserted, in compelling fashion, in such trying circumstances.

\footnotetext{
${ }^{116}$ O’Reilly, 'Edwardian municipal park', 139-40.

${ }^{117}$ Layton-Jones, Uncertain Prospects, 12.
}

Cite this article: Booth N, Churchill D, Barker A, Crawford A (2021). Spaces apart: public parks and the differentiation of space in Leeds, 1850-1914. Urban History 48, 552-571. https://doi.org/10.1017/ S0963926820000449 